\title{
O FUNCIONAMENTO DA IDEIA DE CORPO SEM ÓRGÃOS EM UMA \\ LINGUAGEM ESQUIZOFRÊNICA EM A PAIXÃO SEGUNDO G. H., DE \\ CLARICE LISPECTOR
}

\author{
Jhony Adelio Skeika é doutorando em Estudos Literários pela Universidade Estadual de Londrina, PR. \\ E-mail: jhonyskeika@yahoo.com.br
}

\begin{abstract}
Resumo
Este estudo pretende discutir a ideia de Corpo sem Órgãos (Deleuze; Guattari) no funcionamento da linguagem do livro A Paixão Segundo G. H. (1964), de Clarice Lispector. Considerando que a expressão linguística de $\mathrm{G}$. H. está pautada por um princípio de experimentação e não de interpretação de sentidos fechados, sugerimos que o Corpo sem Órgãos é uma característica esquizofrênica da linguagem da protagonista, que procura se significar e narrar a insólita experiência que teve perante uma barata.
\end{abstract}

\begin{abstract}
This study intends to discuss the idea of Body without Organs (Deleuze; Guattari) inside of the language of The Passion according to G. H. (1964), by Clarice Lispector, Considering this language expression is guided by a principle of experimentation, instead of interpretation of closed meanings, we suggest that Body without Organs is a feature of the main character's schizophrenic language in the process of selfsignification and narration of her experience in front a cockroach.
\end{abstract}

\section{1) Introdução}

Clarice Lispector se destaca na literatura brasileira, dentre outras características, por fazer uso de um discurso que aborda aspectos interiores do ser. Tal sondagem introspectiva, como destaca Benedito Nunes (1995, p. 13-14), é composta de monólogos internos, digressões, fragmentação de episódios, que "sintonizam com o modo de apreensão artística da realidade na ficção moderna". Esse tipo de abordagem na escrita literária está muito próximo ao que, previamente, James Joyce e Virginia Woolf já faziam. Fluxo de consciência pode ser um nome para esta conduta, mas o objetivo deste estudo seria tentar entender a escrita de Clarice Lispector, no recorte que diz respeito ao livro A Paixão Segundo G. H. ${ }^{1}$, lançado em 1964, sob outra ótica.

G. H., personagem principal do texto, é desestabilizada ao contato com sentidos insólitos provindos de uma situação de epifania. A personagem descreve a perda da sua configuração humana, o que significa também perder a proficiência na língua organizada dentro de seu projeto formal de expressão civilizada. Já que não é possível permanecer sem linguagem, G. H. inicia sua busca por uma forma linguística que a represente em seu estado de desorganização e abandono da língua humana. Este artigo, então, se preocupa em acompanhar a protagonista nesse processo de criação daquilo que, com base nas ideias dos filósofos Gilles Deleuze e Félix Guattari, chamamos de Linguagem (escrita) Esquizofrênica².

\footnotetext{
${ }^{1}$ Também será usada, no corpo do texto, a abreviação APSGH para se referir à obra.

${ }^{2}$ Este texto é parte da minha dissertação de mestrado intitulada Uma linguagem (escrita) esquizofrênica: a experimentação de A Paixão Segundo G. H., de Clarice Lispector. Orientação: Profa. Dra. Silvana Oliveira. Instituição: Universidade Estadual de Ponta Grossa, PR.
} 
Com base nas discussões de Deleuze e Guattari ${ }^{3}$, partimos da noção de que APSGH é um livro-máquina e, como um agenciamento, só funciona se estiver conectado a outras máquinas, outros agenciamentos, que fazem o motor-livro trabalhar e produzir sentido. Esse é nosso movimento: conectar $A P S G H$ às ideias de Deleuze e Guattari acerca da Esquizofrenia, para que nesta conexão possamos experimentar possíveis sentidos para o texto literário, em especial para a abordagem da Linguagem utilizada por G. H., a qual parece funcionar de forma desarticulada em relação à língua organizada, em uma atitude daquilo que, a partir nos pensamentos dos filósofos franceses, chamaremos de Corpo sem Órgãos (CsO).

\section{2) A necessidade de linguagem}

A história narrada em APSGH é muito curta e simples: G. H. é uma mulher bem sucedida, escultora, financeiramente independente, moradora de um elegante apartamento de "cobertura", que certo dia precisa limpar sua casa, já que a empregada se despedira. Ao começar a faxina pelo quarto da servente, G.H. se vê confrontada com a limpeza e aridez do cômodo, que de forma irônica abriga a vida dita imunda: uma barata. A personagem entra em um processo de reflexão sobre sua vida e se assusta ao esmagar o inseto contra a porta do guarda-roupa onde ele se encontrava. O episódio termina com a degustação da massa branca que a barata expele.

Obviamente, esta leitura superficial desconsidera a riqueza da construção literária de Clarice Lispector. O que nos interessa são os entremeios, o itinerário de G. H., acompanhá-la em sua desumanização e seu modo de oferecer a experiência por meio do relato, o discurso a que o leitor tem acesso. A autora apresenta a experiência de G. H. pelo ângulo interior da personagem e o texto, mesmo que totalmente articulado em 33 blocos, adquire um movimento caótico quiçá por sugerir o processo psicológico e subjetivo pelo qual a protagonista vai se desestruturando.

G. H. sabe que a experiência insólita do quarto de Janair, a ex-empregada, só pôde acontecer quando ela livrou-se de valores culturais humanos, quando ela passou a viver em um nível sensorial/material e não cultural/social. Para poder voltar à "normalidade" de sentidos a que estava acostumada seria preciso esquecer a experiência esquizofrênica que teve com a barata, mas o simples fato da protagonista resolver narrar o acontecido para reviver já nos é um indício de que ela não quer esquecer e, portanto, seu calvário será no campo da linguagem: como revelar o inumano por meio do mais humano de todos os recursos? Ainda mais se a personagem declara ter perdido sua roupagem humana, o que esperar da expressão da linguagem, sendo esta predicado essencial de um estado de humanidade?

"É difícil perder-se. É tão difícil que provavelmente arrumarei depressa um modo de me achar, mesmo que achar-me seja de novo a mentira de que vivo"

\footnotetext{
3 O Anti-Édipo - capitalismo e esquizofrenia e Mil Platôs - capitalismo e esquizofrenia (obra composta de 15 ensaios divididos em 5 volumes).
} 
(Lispector, 2009, p. 10). G. H. precisa dar uma forma a si mesma, contornar-se e atribuir um confim à sua experiência, mas só poderá fazê-lo pela linguagem.

Deleuze e Guattari afirmam que as máquinas desejantes só funcionam desarranjadas, avariadas, quando desmontam sua integridade maquínica para se conectar a outra máquina e produzir experimentação. Isso seria, segundo os filósofos, uma experiência de Corpo sem Órgãos (CsO), que pode sucintamente ser entendida como uma experimentação não prevista, mas possível, a fim de, pela experiência, gerar sentidos. Seria uma experiência de Corpo sem Órgãos a que G. H. teve acesso, já que experimentou insolitamente a vida crua e neutra da barata, o nó vital, núcleo pulsante, a matéria de Deus? Se o CsO é "uma conquista própria da Esquizofrenia" (Zourabichvili, 2009 , p. 31), estaria a personagem relatando sua experiência em posse de uma expressão de linguagem esquizofrênica já que ela parece ter sido desterritorializada da língua humana organizada? Procuraremos refletir brevemente sobre essas questões nas páginas que se seguem.

\section{3) A experimentação do Corpo sem Órgãos}

Comum ao estilo de escrita de Deleuze e Guattari é a formação de imagens para a experimentação de ideias, noções e pensamentos. Uma das figuras criadas a partir dos estudos desses filósofos é a do Corpo sem Órgãos - CsO. "Ele é não-desejo, mas também desejo. Não é uma noção, um conceito, mas antes uma prática, um conjunto de práticas. Ao Corpo sem Órgãos não se chega, não se pode chegar, nunca se acaba de chegar a ele, é um limite" (Deleuze; Guattari, 1996, p. 9). Essa expressão foi empresta da produção teórico-artística de Antonin Artaud (1896 - 1948), um poeta, dramaturgo e ator francês. Segundo Artaud, a potência do significado só seria liberada quando o corpo organizado se desestruturasse, permitindo uma experiência insólita de experimentação de outras funções, limiares, conexões.

Para além do organismo, mas também como limite do corpo vivido, há o que Artaud descobriu e nomeou: corpo sem órgãos. 'O corpo é o corpo. Ele é único e não precisa de órgãos. O corpo nunca é um organismo'. Os organismos são os inimigos do corpo. $\mathrm{O}$ corpo sem órgãos opõe-se menos aos órgãos do que a essa organização de órgãos chamada organismo. E um corpo intenso, intensivo. E percorrido por uma onda que traça no corpo níveis ou limiares segundo as variações de sua amplitude. $\mathrm{O}$ corpo não tem, portanto, órgãos, mas limiares ou níveis. (cf. Deleuze apud Zourabichvili, 2004, p. $14)$.

CsO é uma ideia que na prática pouco se refere a um corpo propriamente dito; é um devir, uma experimentação não prevista, mas possível, como se o corpo inteligível se projetasse em uma potencialidade a partir do seu limite. É pelo princípio do agenciamento que o $\mathrm{CsO}$ se forma, pelo desejo que move e faz conexões. "O CsO é o campo de imanência do desejo, o plano de consistência própria do desejo (ali onde o desejo se define como processo de produção, sem referência a qualquer instância exterior, falta que viria torná-lo oco, prazer que viria preenchê-lo)" (Deleuze; Guattari, 1996, p. 15). 
Deleuze e Guattari citam o exemplo do Masoquismo como uma das formas de criar um CsO. Para os autores, em uma análise antipsicanalítica, o masoquismo enquanto programa funcionaria como motor de experimentação e de devires autorizados pelo desejo. "A psicanálise faz o contrário ${ }^{4}$ : ela traduz tudo em fantasmas, comercializa tudo em fantasmas, preserva o fantasma e perde o real no mais alto grau, porque perde o CsO" (Deleuze; Guattari, loc. cit.) ${ }^{5}$.

Experimentação e não interpretação: essa é a lógica do Corpo sem Órgãos. Seria falso dizer que o masoquista busca a dor, dizem os autores, pois "ele busca um $\mathrm{CsO}$, mas de tal tipo que ele só poderá ser preenchido, percorrido pela dor, em virtude das próprias condições em que foi constituído" (Deleuze; Guattari, loc. cit.). O Corpo sem Órgãos é uma potencialidade de experimentação, possibilidades de se conectar a outras coisas (inesperadas, às vezes), gerar experiências e passar intensidades.

Talvez o princípio do nome esteja na ideia de que um órgão em conexão com outros órgãos, todos com suas funções pré-estabelecidas pela lógica que rege um organismo, permitiria uma apreensão do todo, mas um limite de funcionamento. “Corpos esvaziados em lugar de plenos" (Deleuze; Guattari, 1996, p. 11): essa seria a proposta.

Será tão triste e perigoso não mais suportar os olhos para ver, os pulmões para respirar, a boca para engolir, a língua para falar, o cérebro para pensar, o ânus e a laringe, a cabeça e as pernas? Por que não caminhar com a cabeça, cantar com o sinus, ver com a pele, respirar com o ventre, Coisa simples, Entidade, Corpo pleno, Viagem imóvel, Anorexia, Visão cutânea, Yoga, Krishna, Love, Experimentação. Onde a psicanálise diz: Pare, reencontre o seu eu, seria preciso dizer: vamos mais longe, não encontramos ainda nosso $\mathrm{CsO}$, não desfizemos ainda suficientemente nosso eu. (Deleuze; Guattari, 1996, p. 11).

Isso também se refere ao princípio de (des/re)territorialidade, já que criar um Corpo sem Órgãos pode ser reprogramar "funções", explorar as potencialidades, desterritorializando aqui para reterritorializar em outro lugar, criando novas possibilidades de significação. Em uma tentativa de elucidar tal ideia, poderíamos pensar nesta proposta a partir da obra do pintor belga Pieter Bruegel, The Elder ${ }^{6}$, do século XVI. Pieter era conhecido pela retratação de paisagens e cenas com trabalhadores, lavradores e camponeses, porém são as representações dos sete pecados mortais ou sete vícios humanos - The Seven Deadly Sins or The Seven Vices - as obras desse pintor renascentista que mais podem contribuir para pensar a noção de $\mathrm{CsO}$.

\footnotetext{
${ }^{4}$ Convém aqui esclarecer que toda e qualquer menção à Psicanálise foi feita a partir da obra de Deleuze e Guattari, visto que o que nos interessa discutir é a visão desses dois filósofos acerca da teoria de Freud.

${ }^{5}$ Fantasma é um termo utilizado pela psicanálise para designar os traumas interiores sofridos pelos seres humanos em suas zonas de desenvolvimento. Segundo Eduardo A. Vidal (1991, p. 98), "produzir, elaborar uma lógica do fantasma é interrogar, de forma permanente, a estrutura do campo do Outro, a estrutura do significante, especificamente a função de corte nessa estrutura". Esse é o trabalho da psicanálise: diagnosticar e tratar a estrutura psicológica do Outro, curando-o de seus fantasmas.

${ }^{6} \mathrm{O}$ sábio; o ancião (tradução nossa).
} 
Em uma dessas obras temos a criação do que seria a luxúria ${ }^{7}$, um dos sete pecados capitais. Como Deleuze e Guattari citam muitos exemplos de como as relações sexuais podem ser um campo fértil para a manifestação do Corpo sem Órgãos, justificase começarmos com esta pintura. Nela, pode-se perceber que os seres ali representados têm seus corpos potencializados, estendidos a partir das inúmeras ligações sexuais. É possível a visualização de diversos devires, um devir-animal do homem, um devirhomem do animal, o prazer sendo encontrado nas mais inusitadas e múltiplas situações. Orgias, espancamentos, mutilações, frenesias, canibalismo, destruição, coisificação, metamorfoses, etc., são alguns aspectos percebidos nesta tela de Bruegel. Os corpos estão tão inusitadamente (des/re)territorializados que até se torna difícil encontrar seus limiares, entender seus agenciamentos e conceber a verossimilhança da representação.

$\mathrm{Na}$ representação da gula ${ }^{8}$ também é possível perceber inúmeros agenciamentos, múltiplas e insólitas conexões, máquinas-boca se conectando a outras máquinas produtoras de fluxos em diversos estados. Criar um $\mathrm{CsO}$ é perceber a potência dos corpos que podem se agenciar e funcionar de qualquer outra forma, seja um corpo trabalhando como casa ou como moinho (reparemos nas imagens do homem-casa e do homem-moinho), seja sendo instrumento de tortura e prazer, no caso do masoquismo, o qual suporta agenciamentos como, no exemplo da figura 1, a coisificação e animalização, já que "o corpo é tão-somente um conjunto de válvulas, represas, comportas, taças ou vasos comunicantes” (Deleuze; Guattari, 1996, p. 13).

É essa potencialidade povoada de intensidade que dá corpo a um Corpo sem Órgãos. Deleuze e Guattari afiram que um $\mathrm{CsO}$ só pode ser experimentado e não produz sentido por interpretação.

Um CsO é feito de tal maneira que ele só pode ser ocupado, povoado por intensidades. Somente as intensidades passam e circulam. Mas o CsO não é uma cena, um lugar, nem mesmo um suporte onde aconteceria algo. Nada a ver com um fantasma, nada a interpretar. O CsO faz passar intensidades, ele as produz e as distribui num spatium ele mesmo intensivo, não extenso. Ele não é espaço e nem está no espaço, é matéria que ocupará o espaço em tal ou qual grau - grau que corresponde às intensidades produzidas. Ele é a matéria intensa e não formada, não estratificada, a matriz intensiva, a intensidade $=\mathrm{O}$, mas nada há de negativo neste zero, não existem intensidades negativas nem contrárias. (Deleuze; Guattari, 1996, p. 13).

De acordo com os filósofos, a psicanálise já havia identificado o fenômeno de criação do $\mathrm{CsO}$, quando se propunha a analisar como o inconsciente se manifestava especificamente em alguns pacientes.

Freud diz que um histérico ou um obsessivo são pessoas capazes de comparar globalmente uma meia a uma vagina, uma cicatriz à castração, etc. Sem dúvida, é ao mesmo tempo que eles apreendem o objeto como global e como perdido. Mas apreender

\footnotetext{
${ }^{7}$ Imagem disponível em $<$ http://www.the-athenaeum.org/art/full.php?ID=38242>. Acesso em 20 mar. 2014.

${ }^{8}$ Imagem disponível em $<$ http://www.the-athenaeum.org/art/full.php?ID=38149>. Acesso em 20 mar. 2014.
} 
eroticamente a pele como uma multiplicidade de poros, de pontinhos, de pequenas cicatrizes ou de buraquinhos, apreender eroticamente a meia como uma multiplicidade de malhas, eis o que não viria à cabeça de um neurótico, enquanto que o psicótico é disto capaz: "acreditamos que a multiplicidade das pequenas cavidades impediria o neurótico de utilizá-las como substitutos dos órgãos genitais femininos". Comparar uma meia a uma vagina, ainda passa, isto é feito todos os dias, mas um puro conjunto de malhas a um campo de vaginas, só mesmo sendo louco: é isto que diz Freud. (Deleuze; Guattari, 1995, p. 40. Sem grifos no original).

Podemos até entender o posicionamento de Freud frente a um $\mathrm{CsO}$, pois obviamente esse tipo de percepção da vida é um tanto incomum a um padrão conceitual que julga "normal" as coisas estarem nos seus devidos lugares, nos quais foram projetadas para funcionar. Seria loucura, então, perceber a vida pela ótica do Corpo sem Órgãos, conceber algumas representações Pieter Bruegel, The Elder ${ }^{9}$, permitir que se intensifiquem as múltiplas conexões potencialmente capazes de gerar prazer, mas que regressam ao desejo fazendo o rizoma ${ }^{10}$ funcionar por movimentos de velocidade e de (des/re)territorialização subvertendo a lógica dos sentidos? Segundo François Zourabichvili (2009, p. 31), o Corpo sem Órgãos é "uma conquista própria da Esquizofrenia".

Por mais que a obra de Deleuze e Guattari não preveja uma atitude conclusiva, para o recorte aqui proposto, é possível perceber que o caminho de reflexão trilhado por eles culmina em outro platô, talvez um grande platô, um espaço de acesso e encontro de rizomas, máquinas desejantes e Corpo sem Órgãos. Discutir Capitalismo e Esquizofrenia é, talvez, a grande motivação desses filósofos, e sua produção desejante opera por sugerir uma nova visão para a Esquizofrenia, que pode ser vista não como uma doença, mas como uma proposta, uma resposta, uma intensidade, uma abordagem.

A noção de Esquizofrenia e $\mathrm{CsO}$ será operacional neste estudo tanto para o tratamento de nosso objeto de estudo enquanto manifestação literária experimentável e não interpretável, quanto para acompanharmos o itinerário da protagonista de $A$ Paixão Segundo G. H. . Se o Corpo sem Órgãos é uma experimentação esquizofrênica, então nos interessa pensar como a linguagem do livro e de G. H. opera a partir dessas ideias.

\section{4) O CsO da Linguagem Esquizofrênica de G. H.}

Segundo Deleuze e Guattari, o esquizofrênico sofre por estar desorganizado, alheio ao sistema. É muito próximo o sofrimento de G. H. que se sente desterritorializada, desarticulada, já que provou por algumas horas um puro fluido de vida, um devir-barata de G. H., um devir-G. H. da barata. Seria uma experiência de

\footnotetext{
${ }^{9}$ Há mais outras cinco pinturas de Pieter Bruegel, The Elder, que retratam respectivamente a raiva, avareza, preguiça, orgulho e a inveja, nas quais é possível perceber uma multiplicidade de agenciamentos insólitos.

${ }^{10}$ A noção de rizoma proposta por Deleuze e Guattari é uma matriz teórica potencialmente capaz de ser associada a diversas áreas do conhecimento, produzindo um método de análise. Segundo os autores, há seis características que regem o rizoma: os princípios de conexão, heterogeneidade, multiplicidade, ruptura a-significante, cartografia e decalcomania (Deleuze; Guattari, 1995, p. 15 - 21).
} 
Corpo sem Órgãos a que a protagonista teve acesso? Experimentação potencial e desestruturante.

Estarão as máquinas suficientes desarranjadas, e suas peças suficientemente desligadas, para se entregarem e nos entregarem ao nada? Dir-se-ia que os fluxos parciais são ainda estão muito ligados, que os objetos parciais ainda são orgânicos em demasia. Mas o puro fluido, em estado livre e sem cortes, está em vias de deslizar sobre um corpo pleno. As máquinas desejantes fazem de nós um organismo: mas, no seio dessa produção, em sua própria produção, o corpo sofre por estar assim organizado, por não ter outra organização ou organização nenhuma. (Deleuze; Guattari, 2010, p. 20. Sem grifos no original).

G. H. se vê em uma situação de falta de controle e isso pode ser causado pela ausência de linguagem, território do qual também parece ter sido desterritorializada (“Cada vez preciso menos me exprimir. Também isto perdi?” - Lispector, 2009, p. 19). A linguagem em seu modelo significante/significado não seria suficiente para contornar os estados insólitos vividos pela protagonista. Ela mesma admite essa precariedade do signo linguístico: "Será preciso coragem para fazer o que vou fazer: dizer. E me arriscar à enorme surpresa que sentirei com a pobreza da coisa dita. Mal a direi, e terei que acrescentar: não é isso, não é isso!" (Lispector, 2009, p. 18). A personagem precisará, então, dizer e desdizer, dizer e redizer, e neste processo a narrativa vai se tornando um labirinto.

Segundo Deleuze e Guattari (2010, p. 29), “embaralha todos os códigos, num deslizamento rápido, conforme as questões que se lhe apresentam, jamais dando seguidamente a mesma explicação, não invocando a mesma genealogia, não registrando da mesma maneira o mesmo acontecimento". Muito parecido a isso é o movimento de G. H., que fica deambulando pela linguagem, fazendo contornos, explicando, refletindo, percorrendo os mesmo sentimentos de diversas formas, usando da língua para passear sobre sua experiência, como se procurasse a melhor forma para dizer o que deve ser dito e, não encontrando, passasse à prolixidade, "pecando por excesso" de língua", recriando novamente o que já se esforçara para dar forma. É no processo de deambulação que a experiência vivida se atualiza, é uma escolha que opta por ser excessiva, por saturar-se e trazer, de alguma forma, o aroma daquilo que foi experimentado, mesmo que apenas pela sugestão possível da palavra.

A protagonista tenta criar um discurso para representar a experiência vivida, mas o que ela viveu é incompreensível, inexprimível e não pode ser acabado pela língua humana. É a visão de um grande pedaço de carne, ou melhor, de uma carne infinita que é a visão dos loucos. Ela sabe que se ela "cortar a carne em pedaços e distribuí-los pelos

11 Cabe esclarecer que aqui o termo prolixidade ou a expressão pecar por excesso nada tem de depreciativo. Pelo contrário, é nesse movimento, que normativamente poderia ser chamado de exagero, que G. H. presentifica sua experiência. É o que Deleuze e Guattari (2010, p. 29) sugeriram ao afirmar que o esquizofrênico jamais apresenta seguidamente a mesma explicação e não registra da mesma maneira o mesmo acontecimento. G. H., nesse discurso esquizofrênico, acaba por fazer um movimento deambulante na língua, exagerado, repetitivo, mas isso faz parte de sua forma de significação e atualização experiencial. 
dias e pelas fomes", então a carne infinita "não será mais a perdição e a loucura", mas "será de novo a vida humanizada" (Lispector, 2009, p. 12). Porém, voltar à humanidade nessas condições é uma atitude esquizofrênica, já que para a sua experiência vivida, uma carne infinita é verossímil, mas para os moldes da linguagem e da cultura humana dar contorno ao incoerente, e assim admiti-lo em seu caráter inexpressivo, é sutilmente loucura.

G. H. está nesse impasse, pois cortar a carne e ajustá-la ao tamanho dos olhos e da boca é um modo de integrar nela mesma a sua própria desintegração, mas seria um jeito de entender.

\begin{abstract}
Já que tenho de salvar o dia de amanhã, já que tenho que ter uma forma porque não sinto força de ficar desorganizada, já que fatalmente precisarei enquadrar a monstruosa carne infinita e cortá-la em pedaços assimiláveis pelo tamanho de minha boca e pelo tamanho da visão de meus olhos, já que fatalmente sucumbirei à necessidade de forma que vem de meu pavor de ficar indelimitada - então que pelo menos eu tenha a coragem de deixar que essa forma se forme sozinha como uma crosta que por si mesma endurece, a nebulosa de fogo que se esfria em terra. E que eu tenha a grande coragem de resistir à tentação de inventar uma forma. Esse esforço que farei agora por deixar subir à tona um sentido, qualquer que seja, esse esforço seria facilitado se eu fingisse escrever para alguém. (Lispector, 2009, p. 13. Sem grifos no original).
\end{abstract}

Não fica claro se o movimento de G. H. é o da escrita, mas de qualquer forma é um discurso que se pauta pelo "agora", pela presentificação da experiência. G. H. confia, então, nas relações e nas lacunas que sua "nova linguagem" oferece já que seu esforço será sempre frustrado pela limitação do código organizado. Então lhe resta o desafio de agarrar-se às tábulas das palavras e ir experimentando significados e imagens até recriar alguns sentidos do que lhe aconteceu, mesmo sabendo que nunca conseguirá contar tudo (Lispector, 2009, p. 163); ela assume, veladamente, que os significados escapam da palavra humana e por isso é necessário recorrer a outros signos.

Aqui, gostaríamos de chamar de esquizofrênica essa conduta da linguagem de G. H., já que foge à estrutura de língua, é embaralhada, labiríntica e opera pelo movimento de experimentação, sendo esta a lógica linguística mais significativa. Porém, não há modelo a se seguir assim como há na expressão de linguagem institucionalizada, por isso a personagem afirma que deverá deixar essa sua língua se formar aleatoriamente, como uma crosta que por si mesma endurece.

Sua expressão linguística experimental é bruta e em estado vivo, como uma ferida que vai cicatrizando aos poucos, como o branco da barata, que se oferece leitoso e fresco, mas que já começa a endurecer e amarelar em crosta assim que toca o ar. Assim é a linguagem de G. H., nunca é no "agora", só pode ser presente no justo momento em que é processo puro de enunciação; a personagem quer tocar na vida que escapa, descrever com nomes uma manifestação amorfa, a fim de retê-la ao menos nas significações da língua, desejando sua imanência. Mas a dura verdade é que o momento de comer a massa branca da barata já é um instante amarelado.

Segundo Deleuze e Guattari (2010, p. 59), 
o esquizo está no limite dos fluxos descodificados do desejo; seria preciso entender, também assim, os códigos sociais, já que, nestes, um Significante despótico esmaga todas as cadeias, as lineariza, as bi-univociza, e se serve dos tijolos como se fossem elementos imóveis para uma muralha da China imperial. Mas os esquizo os destaca sempre, desliga-os e os leva consigo em todos os sentidos para reencontrar uma nova plurivocidade, que é o código do desejo. Toda composição, assim como toda decomposição, se faz com tijolos móveis.

Deleuze e Guattari descrevem o comportamento esquizofrênico como aquele que não faz uso de estruturas estanques de significação. Se pensarmos a língua como um código social então temos o esquizo embaralhando seus tijolos (signos), desfazendo ligações lógicas coerentes ao código para encontrar uma nova plurivocidade, novas vozes que operam por novos sentidos; por desejo, os tijolos linguísticos são dispostos das mais inusitadas formas.

Em A Paixão Segundo G. H. podemos perceber a formação de imagens que operam na criação de sentidos, mas não podem ser interpretadas de maneira fechada. Um exemplo disso é quando a personagem está descrevendo o quarto da empregada e afirma: "O quarto era o retrato de um estômago vazio. [...] Tudo ali eram nervos seccionados que tivessem secado suas extremidades em arame” (Lispector, 2009, p. 42). O leitor é convidado a experimentar essas imagens desconectadas: a imagem do estômago e dos nervos por si só podem ser significadas na experimentação da leitura. G. H. cria na posse de sua expressão linguística esquizofrênica e o leitor é chamado a experimentar o quente e branco do sol que adentra o quarto da empregada, visitar uma caverna ou um deserto árido e seus animais, ouvir sons de guizos de cascavel, vislumbrar uma barata grossa ou camadas de baratas como "o negror de centenas e centenas de percevejos, conglomerados uns sobre os outros" (Lispector, 2009, p. 47), uma alegria de inferno inexprimível. Como por desejo, APSGH convida o leitor a criar um Corpo sem Órgãos, imagens e sons que só têm sentido pela experimentação sensorial que a leitura presentifica.

A menos que eu pudesse fazer a prece verdadeira, e que aos outros e a mim mesma pareceria a cabala de uma magia negra, um murmúrio neutro. Esse murmúrio, sem nenhum sentido humano, seria a minha identidade tocando na identidade das coisas. Sei que, em relação ao humano, essa prece neutra seria uma monstruosidade. Mas em relação ao que é Deus, seria: ser. (Lispector, 2009, p. 134. Sem grifos no original)

Eis a prece verdadeira, a busca secreta das religiões que desterritorializam suas línguas para se aproximarem do núcleo incompreensível do divino. Um murmúrio, sílabas desconexas, onomatopeias, silêncio. Seria essa a conduta da língua que poderia ser usada naquele quarto? Grunhidos, ruídos, chiados, uma ex-humana se aproximando da identidade neutra da vida, de uma barata, fazendo uma prece monstruosa àquilo que parecia "ser" o Deus. "Há três mil anos desvairei-me, e o que restaram foram fragmentos fonéticos de mim" (Lispector, 2009, p. 20). 
Porém, já que sem linguagem nada é narrável, e ela se propôs ao relato do que foi vivido, então as horas de perdição no quarto de Janair vão sendo recriadas em um estilo experimental, traduzidas em sinais de telégrafo, em uma linguagem sonâmbula, que não seria linguagem se a protagonista estivesse acordada (Lispector, 2009, p. 19). Essa língua que se forma, a qual chamamos esquizo, poderia ser entendida com o Corpo sem Órgãos da linguagem organizada.

A expressão esquizofrênica é rizoma e opera pela lógica do $\mathrm{CsO}$. G. H cria potencialidades e transcende o fato projetando sobre ele toda sua introspectiva visão. A experiência relatada pela protagonista é uma malha rizomática que nos autoriza inúmeras entradas, fugas e agenciamentos e isso só nos é possível porque não há uma linguagem despótica operando na criação semântica.

Entretanto, o tecido discursivo de G. H. nem sempre é desordenado. Podemos dizer que há picos de esquizofrenia em sua linguagem, há momentos em que conseguimos acompanhar seu itinerário narrativo, atribuímos significados às suas metáforas e explanações. Porém, há trechos em que a linguagem sucumbe e é impossível propor uma interpretação padrão e aceitável semanticamente no contexto da língua humana, já que a linguagem torna-se um emaranhado desordenado de imagens e palavras boiando desconectadas do todo orgânico que o romance pretende ser. Um exemplo claro de como isso acontece está no capítulo doze.

Finalmente, meu amor, sucumbi. E tornou-se um agora. Era finalmente agora. Era simplesmente agora. Era assim: o país estava em onze horas da manhã. Superficialmente como um quintal que é verde, da mais delicada superficialidade. Verde, verde - verde é um quintal. Entre mim e o verde, a água do ar. A verde água do ar. Vejo tudo através de um copo cheio. Nada se ouve. No resto da casa a sombra está toda inchada. A superficialidade madura. São onze horas da manhã no Brasil. É agora. Trata-se exatamente de agora. Agora é o tempo inchado até os limites. Onze horas não têm profundidade. Onze horas está cheio das onze horas até as bordas do copo verde. $\mathrm{O}$ tempo freme como um balão parado. $\mathrm{O}$ ar fertilizado e arfante. Até que num hino nacional a badalada das onze e meia corte as amarras do balão. E de repente nós todos chegaremos ao meio-dia. Que será verde como agora. Acordei de súbito do inesperado oásis verde onde por um momento eu me refugiara toda plena. (Lispector, 2009, p. 79. Sem grifos no original).

G. H. se entrega ao "agora" como uma sonâmbula sai desesperada ao encontro da experiência e sua linguagem perde a noção de unidade, coesão, coerência em favor da experimentação de sensações que vão sendo descritas por imagens inusitadas. Essa linguagem quer gerar inusitados sentidos que não foram ainda convencionados na lógica do mundo, como por exemplo experimentar a sensação de ser um copo arfante, inchado e cheio de onze horas verdes de um balão. É a tentativa de superação da relação significante e significado e de seu condicionamento no contexto semântico, sintático e morfológico da língua, o que nos autoriza a criar signos novos que podem ser incorporados, sem nenhum prejuízo, à máquina da linguagem. Eis uma língua que não está descrevendo simples construções, o desejo é sê-las ao mesmo tempo em que elas são. A linguagem esquizofrênica é a materialização do próprio tempo presente, pois 
"trata-se exatamente de agora" e "agora é o tempo inchado até os limites" (Lispector, 2009, loc. cit.).

Talvez pudéssemos sugerir um tempo verbal de enunciação dessa linguagem (escrita) esquizofrênica: o presente do indicativo, já que sempre que G. H. tenta dele se aproximar é sucumbida por uma expressão caótica e experimental.

G. H. sugere, pelo desprezo da organização linguística, uma adesão completa a uma conduta de linguagem esquizofrênica, como se sua mais profunda prece fosse feita em tons inaudíveis de sons desconexos e desterritorializados. Neste protocolo linguístico, o que ela disser não pode fazer sentido e o leitor é convidado a acompanhar essa experiência que é apenas fonética (gráfica) e não semântica, pois o que está sendo narrado é "inegavelmente uma verdade anterior a nossas palavras" (Lispector, 2009, p. 118 - 119):

Lembro-me de minhas dores de garganta de então: as amídalas inchadas, a coagulação em mim era rápida. E facilmente se liquefazia: minha dor de garganta passou, dizia-te eu. Como geleiras no verão, e liquefeitos os rios correm. Cada palavra nossa - no tempo que chamávamos de vazio - cada palavra era tão leve e vazia como uma borboleta: a palavra de dentro esvoaçava de encontro à boca, as palavras eram ditas mas nem as ouvíamos porque as geleiras liquefeitas faziam muito barulho enquanto corriam. No meio do fragor líquido, nossas bocas se mexiam dizendo, e na verdade só víamos as bocas se mexendo mas não as ouvíamos - olhávamos um para a boca do outro, vendo-a falar, e pouco importava que não ouvíssemos, oh em nome de Deus pouco importava. $\mathrm{E}$ em nome nosso, bastava ver que a boca falava, e nós ríamos porque mal prestávamos atenção. E no entanto chamávamos esse não ouvir de desinteresse e de falta de amor. Mas na verdade como dizíamos! dizíamos o nada.

Essas imagens nos conduzem a pensar que a desterritorialização da língua acontece até em seus constituintes fisiológicos, como o aparelho fonador, as zonas de articulação e as cavidades internas da boca. É porque na língua humana e organizada as palavras se coagulam para poderem ser proferidas, mas a linguagem esquizofrênica quer, antes que o branco amarele, os espermatozoides morram e o sangue coagule, tocar no que é vivo no presente do indicativo. Não falar com a boca, desorganizar os sons, não articulá-los, deixando a palavra voar como uma borboleta sem peso significativo: os signos não têm mais sua função de representação, é um inseto alado de voa na cavidade articulatória do aparelho fonador, batendo em suas paredes mucosas, esvoaçando significantes sem significado. Experiência de Corpo sem Órgãos, desterritorialização do organismo produtor de sons, máquina-boca desejante, avariada, desregulada e descontrolada, arfando palavras-borboleta não programadas.

Seria a dicção neutra do silêncio esta expressão de que G. H. faz uso? Uma linguagem esquizofrênica, desestruturada, desconexa, sem sentido, como um cão que cava buracos, ratos rizomáticos se tocando freneticamente em suas tocas, a língua lamuriante dos anjos, fragmentos fonéticos desarticulados proferidos num êxtase espiritual que por si só não tem significado e antes é uma ladainha sinestésica: "A vibração do calor era como a vibração de um oratório cantado. Só minha parte auricular sentia. Cântico de boca fechada, som vibrando surdo como o que está preso e 
contido, amém, amém. Cântico de ação de graças pelo assassinato de um ser por outro ser". (Lispector, 2009, p. 81. Sem grifos no original).

O seu aparelho auricular é desterritorializado da função de audição e passa a sentir a ressonância do som inaudível do quarto de Janair. A dicção atonal do deserto do quarto da empregada de G. H. era como a de um cântico monótono, uma ladainha, um oratório todo cantando de bocas fechadas. "E ia para essa loucura promissora" (Lispector, 2009, p. 59). O som do silêncio daquele quarto era a manifestação de uma linguagem esquizofrênica e G. H. é movida a desterritorializar a articulação fonética do código até "chegar a gaguejar na sua própria língua" (Deleuze; Parnet apud Dinis, 2001, p. 16).

Poderíamos dizer que essa conduta da linguagem de G. H. nos remete ao funcionamento do Corpo sem Órgãos, visto que uma língua desenraizada na tradição linguística pode operar por representar, sim, inusitadas experiências esquizofrênicas. Segundo François Zourabichvili (2009, p. 31) ${ }^{12}$, “o esquizofrênico responde com seus "gritos-sopros", fusão das palavras ou das sílabas tornadas indecomponíveis, à qual corresponde o novo vivido de um corpo pleno, sem órgãos distintos". Para esse teórico, que se propôs a "traduzir" algumas noções de Gilles Deleuze, o estado de CsO opera "numa zona dita de "profundidade" onde a organização de "superfície", que garante o sentido ao manter a diferença de natureza entre corpo e palavras, é de toda forma perdida" (Zourabichvili, loc. cit.).

É muito difícil destituir-se da linguagem, já que é nossa pata humana, nosso esforço sensível de transcendência. Conhecemos o mundo pelas construções arquitetadas na/pela língua, por isso é então intenso o sofrimento de G. H., sua Paixão é depor a língua e toda a significação transcendente que ela evoca - talvez seja esse um dos sentidos a que o título do livro possa se referir. O caminho do calvário percorrido é sua rota para o assassinato profundo da língua como intermediária constante entre a personagem e o mundo, um crime contra si mesma já que G. H. é linguagem e esforçouse a vida toda para enquadrar-se nela.

Esse é seu caminho de sofrimento e ela não resiste às quedas, sua salvação contra a dor é recorrer novamente à língua para se significar e assim a narrativa vai sendo construída e é só por isso que a narrativa existe, porque G. H. não resistiu ao vício humano de nomear. Ela precisou voltar desesperadamente ao uso da língua, mesmo que agora sua expressão de linguagem seja mais um grafismo que uma escrita, mais uma reprodução que uma expressão, mais fragmentos fonéticos desarticulados que um discurso, mais esquizofrenia que significação.

Representar o mundo por uma linguagem desarticulada fez parte da agonia de G. H. em sua Paixão, bem como sua desestruturação dos valores humanos e sua aproximação à selvageria do mundo, comungando da vida neutra que se manifesta em todos os seres.

\footnotetext{
${ }^{12} \mathrm{O}$ vocabulário de Deleuze.
} 


\section{Algumas considerações}

Literatura e esquizofrenia aqui estão associadas, já que uma linguagem (escrita) esquizofrênica poderia potencializar a conduta literária de criar agenciamentos, experimentação, Corpo sem Órgãos, devires, pois opera na desterritorialização do código linguístico, como tentamos discutir neste texto. Nosso objetivo aqui foi o de aproximar a noção de Literatura a um princípio esquizofrênico, antes até a uma dinâmica esquizofrênica, não só na linguagem, mas também no jogo do mundo, de modo a reconhecer essa dinâmica no funcionamento do discurso esquizo no texto de $A$ Paixão Segundo G. H., de Clarice Lispector.

G. H. quis libertar-se da moralidade, porque para viver o inferno não é possível ter sentimentos humanos de culpa e arrependimento, mas mergulhar no pecado moral e lá ficar. A identidade humana, segundo G. H., é a expressão de uma alegria de gozo infernal, é a matéria que vibra pelo sangue quente que pulsa e que para ser mais intenso precisa jorrar para fora do corpo: carnificina, canibalismo, masoquismo, Corpo sem órgãos, experimentação, rituais demoníacos de sacrifício. É o sofrimento intenso, o golpe fatal do amor, Paixão. "Só a misericórdia do Deus poderia me tirar da terrível alegria indiferente em que eu me banhava, toda plena. Pois eu exultava. Eu conhecia a violência do escuro alegre - eu estava feliz como o demônio, o inferno é o meu máximo" (Lispector, 2009, p. 125).

A moralidade é castração da experiência de Corpo sem Órgãos, é a retração da volúpia, do gozo, da orgia, do sangue que jorra do corpo alheio. O inferno é caos, é a intertroca constante dos seres vivos que compartilham, em todos os sentidos, as matérias de que são feitos a fim de dividir seu núcleo de vida, sua identidade, seu pedaço de Deus; no inferno há "a fé na vida orgíaca. A orgia do inferno é a apoteose do neutro. A alegria do sabá é a alegria de perder- se no atonal” (Lispector, 2009, p. 121).

Corpo sem Órgãos, neste texto, foi entendido como uma potencialidade de experimentação que desautomatiza a linguagem organizada dentro de um princípio de humanidade. G. H. quer se aproximar do selvagem, cru, neutro, da vida da barata, mas para experimentar esse inferno, que é destituir-se da roupagem cultural e linguística, chegar ao nível mais elementar de vida, a protagonista precisou desviciar-se dos princípios moralizantes que regem um protocolo de humanidade e exercitar uma dicção de linguagem experimental, uma linguagem esquizofrênica, desarticulada, a fím de experimentar os possíveis sentidos vividos naquele inferno no quarto de Janair.

\section{5) Referências}

BRUEGEL, P. The Seven Deadly Sins or The Seven Vices: Gluttony. 1557.230 x 300 $\mathrm{mm}$. Biblioteca Real Alberto I, Sala das Gravuras, Bruxelas, Bélgica. Disponível em: $<\mathrm{http}: / /$ www.the-athenaeum.org/art/full.php?ID=38149>. Acesso em 20 mar. 2014. 
. The Seven Deadly Sins or The Seven Vices: Lechery. 1557. 225 x $296 \mathrm{~mm}$ Biblioteca Real Alberto I, Sala das Gravuras, Bruxelas, Bélgica. Disponível em: $<$ http://www.the-athenaeum.org/art/full.php?ID=38242>. Acesso em 20 mar. 2014.

DELEUZE, G.; GUATTARI, F. Mil platôs: capitalismo e esquizofrenia, vol. 1. Tradução de Aurélio Guerra Neto e Celia Pinto Costa. São Paulo: Ed. 34, 1995.

Mil platôs: capitalismo e esquizofrenia, vol. 3. Tradução de Aurélio Guerra Neto, Ana Lúcia de Oliveira, Lúcia Cláudia Leão e Suely Rolnik. São Paulo: Ed. 34, 1996.

O Anti-Édipo: capitalismo e esquizofrenia 1. Tradução de Luiz B. L. Orlandi. São Paulo: Ed. 34, 2010.

DINIS, N. A arte da fuga em Clarice Lispector. Londrina: Ed. UEL, 2001.

LISPECTOR, C. A Paixão Segundo G. H.. Rio de Janeiro: Rocco, 2009.

NUNES, B. O Drama da Linguagem - uma leitura de Clarice Lispector. 2 ed. São Paulo: Ática, 1995.

VIDAL, E. A. Sobre o fantasma. In. Letra Freudiana. Rio de Janeiro, vol. 1, n. 9, p. 95 - 98, 1991. Disponível em: <http://www.escolaletrafreudiana.com.br/UserFiles/110/ File/artigos/letra09/012.pdf>. Acesso em 05 jan. 2012.

ZOURABICHVILI, F. O vocabulário de Deleuze. Tradução de André Telles. Rio de Janeiro: Relume Dumará; Sinergia; Ediouro, 2009. 